DOI: $\underline{10.35619 / \mathrm{iiu} . \mathrm{v} 2 \mathrm{i} 13.335}$

Денисова Світлана

викладач іноземної мови комунального закладу вищої освіти «Луцький педагогічний коледж»

Волинської обласної ради, м. Луцьк, Україна

ORCID: 0000-0001-9352-7036 e-mail: 1denusova.svitlana@gmail.com

Кузьмич Оксана

викладач іноземної мови комунального закладу вищої освіти «Луцький педагогічний коледж»

Волинської обласної ради, м. Луцьк, Україна

ORCID: 0000-0002-1335-3791

e-mail: kuzmych.o@ukr.net

Ніколасва Ірина

викладач іноземної мови комунального закладу вищої освіти «Луцький педагогічний коледж»

Волинської обласної ради м. Луцьк, Україна

ORCID: 0000-0002-2949-0002 e-mail:iri5272@ukr.net

\title{
МОТИВАЦІЯ ВИВЧЕННЯ ІНОЗЕМНИХ МОВ У ЗАКЛАДАХ ВИЩОЇ ОСВІТИ
}

Анотація. У статті висвітлено проблему мотивації вивчення іноземних мов у закладах вищої освіти. Здійснено опис та узагальнення основних різновидів мотивації, іï структури і ролі при вивченні іноземної мови у вищій школі, розглянуто основні характеристики мотивації та їх зв язок з процесом навчання. Мотивація розглядається як управлінська діяльність під час навчання іноземної мови і як одна з головних проблем методики іiі викладання. Іноземна мова як навчальна дисципліна має чимало специфічних особливостей, одна з яких - оволодіння іноземною мовою у процесі вироблення умінь та навичок здійснювати іншомовне спілкування. В умовах сьогодення актуальність вивчення іноземної мови не підлягає сумніву, оскільки розвиток сучасного суспільства, розширення міжнародного співробітництва і міжнародних контактів, проведення у закладах вищої освіти конференцій за участю іноземців вимагають від студентів більш глибокого знання іноземної мови.

(C) Денисова С., Кузьмич О.,

Ніколаєва I., 2021 


\section{Інноватика у вихованні. Випуск 13.Том 2. 2021.}

Досліджено проблему мотивації студентів до вивчення іноземних мов під час навчання у закладі вищої освіти; описано наявні види мотивації та iii домінуючу роль у процесі вивчення іноземних мов студентами. Окремо розглянуто роль рівня педагогічної майстерності викладача, що сприяє мотивації студентів до вивчення іноземних мов. Окреслено основні різновиди внутрішньої мотивації студента у контексті навчання іноземної мови. Зазначено ієрархічність та шляхи формування навчальної мотивації студентів.

Ключові слова: мотивація, студент, заклад вищої освіти, навчання іноземної мови, мотиваційні фактори, майстерність викладача.

Постановка проблеми. Сучасний розвиток людства, процес всесвітньої економічної, політичної та культурної інтеграції усіх сфер суспільних взаємовідносин зумовлюють зростання потреб у вивченні іноземних мов, а проблема мотивації в навчанні іноземних мов стає досить актуальною. Даний процес демонструє, що все більшого значення набуває роль особистих контактів людей, i, відповідно, вербальної комунікації, зпоміж них й міжнаціональної, яка потребує знання іноземних мов (Скакун та Матіюк, 2018).

Як засвідчує практика навчання іноземної мови, особливої уваги потребує дослідження питання мотивації у контексті ії вивчення. Саме на цьому ми і зосередимось докладніше.

На нинішньому етапі розвитку суспільства знання іноземної мови значно сприяє розвитку міжнародних відносин у галузі науки і освіти, відповідно, підвищуються вимоги до підготовки фахівців різних сфер, в т.ч. й освіти та науки. Комунікабельність, вміння здійснювати письмову та усну комунікацію $з$ діловими і науковими партнерами, брати участь у переговорах, $є$ конкурентною перевагою, що, за твердженням Ф. Котлера, сприяє виходу на нові ринки і збільшення доходів; більш осмислене спілкування, передачі міжнародного досвіду лідерам і клієнтам (Котлер, 2014).

Нині англійська мова, як мова міжнародного спілкування, є каналом для залучення українського народу до цивілізаційного прогресу, що відбувається в усіх сферах життя людей. Оволодіння англійською мовою широкими верствами населення стимулюватиме імплементацію в українське суспільство світових досягнень економічної, політичної, правової, моральної культури, що конче необхідно для модернізації суспільного життя людей в Україні. (Костенко, 2012).

Як правило, вивчення іноземної мови починається в початковій школі, продовжується у середній школі, а у закладі вищої освіти цей процес набуває професійного спрямування. Аби навчальний процес був ефективним і приніс бажані результати, необхідну і важливу роль відіграє мотивація (Штохман, 2017). 


\section{Інноватика у вихованні. Випуск 13.Том 2. 2021.}

Мета статті - розглянути роль мотивації в навчанні іноземної мови, виокремити ii основні компоненти, виявити вплив мотивації на підвищення рівня освітньо-виховного процесу в закладах вищої освіти.

Виклад основного матеріалу. Мотиваційна сфера особистості утворюється системою мотивів, які виконують функцію спонукання, спрямування і регулювання діяльності. Питанням мотиваційної сфери, стимулам навчальної діяльності особистості присвячено багато досліджень педагогів (Ю. К. Бабанський, В. О. Сухомлинський, Г. І. Щукіна та ін.), психологів (Б. Г. Ананьєв, Л. І. Божович, О. М. Леонтьєв, С. Л. Рубінштейн та ін.), соціологів (О. Г. Здравомислов та ін.). Важливі проблеми формування мотивації навчання досліджували українські дидакти (В. К. Буряк, В. С. Веретільник, О. І. Чорний та ін.) (Рубан, 2014).

Значне місце у формуванні мотиваційної сфери відіграють суспільні інститути, насамперед ті людські спільноти, до яких належить індивід. Оскільки індивід є членом великої кількості людських спільнот, то розвиток мотиваційної сфери слід розглядати не як процес «зсередини» індивіда, а в контексті розвитку його зв'язків з різними людськими спільнотами. Таким чином, перехід від одного рівня мотивації до іншого визначається не законами спонтанного розвитку індивіда, а розвитком його стосунків і зв'язків з іншими людьми, із суспільством загалом. Тому до цього поняття потрібно підходити комплексно, враховуючи всі можливі аспекти (Знанецький, 2020).

Як стверджують психологи, однією 3 найактуальніших проблем сучасної педагогіки $є$ постійна підтримка та розвиток навчальної діяльності, забезпечення сприятливого емоційного клімату на заняттях. Особливу складність у вивченні іноземних мов дотепер представляє недостатньо сформована мотиваційна сфера студентів.

Мотивація у вивченні іноземних мов за своєю природою являє собою сукупність дій, які застосовує викладач, 3 метою ініціювання, зацікавлення, активізації навчальних груп для досягнення ефективності у навчанні (Латишев, 2003). По-перше, можливий вплив соціальних мотивів, які визначаються потребами суспільства. Такі мотиви у своїй сукупності формують зовнішню мотивацію, яка існує у двох різновидах: як широка соціальна i вузькоособистісна мотивація. По-друге, на мотиваційноспонукальну сферу людини може впливати і характер діяльності. Це так звана внутрішня мотивація і ії підвидом є мотивація успішності. Зовнішня i внутрішня мотивація носять позитивний і негативний характер (Бей, 2018).

Схарактеризуємо основні різновиди внутрішньої мотивації студента стосовно навчання іноземної мови.

Комунікативний різновид внутрішньої мотивації є основним, тому що комунікативність - це перша і природна потреба особистості, яка вивчає іноземну мову. Спеціально проведені соціологічні опитування засвідчують про те, що незалежно від віку й соціального статусу всі 


\section{Інноватика у вихованні. Випуск 13.Том 2. 2021.}

студенти усвідомлено й однаково формулюють свої потреби як суто комунікативні, а саме: оволодіння усним та писемним мовленням, що включає уміння спілкуватися іноземною мовою 3 колегами, друзями, уміння читати професійно-орієнтовану літературу, уміння вільно висловлювати свої думки на письмі.

Однак, незважаючи на таку виражену зацікавленість до спілкування іноземною мовою 3 боку студентів, саме цей тип мотивації найважче зберегти. Свідоме ставлення носіїв мови до своєї комунікативної діяльності, вміння будувати своє усне і письмове мовлення, розуміти й адекватно реагувати на чужу мову, переконливо відстоювати власну позицію, дотримуючись мовних й етико-психологічних правил поведінки, стають визначними факторами успішної комунікації в сучасному діловому світі (Штохман, 2017).

Наступним різновидом внутрішньої мотивації слід вважати лінгвопізнавальну, яка полягає в позитивному ставленні студентів до самої «мовної матерії», до вивчення основних якостей мовних знаків. Можливі два шляхи іiі формування: опосередкований, тобто через комунікативну мотивацію, і безпосередній, шляхом стимулювання пошукової діяльності студентів у мовному матеріалі.

Для того, аби викликати інтерес студентів до мовного «будівельного матеріалу», слід: по-перше, звести до мінімуму часовий розрив у роботі над мовним матеріалом і його застосуванням у мовленні задля того, щоб студенти бачили мовленнєву перспективу його застосування; по-друге: віддавати перевагу настанові, що стосується роботи над мовним матеріалом, цілеспрямований мовний характер, що формує мовну перспективу; по-третє, мовний матеріал, який має засвоюватися на занятті, слід орієнтувати на конкретну тематику, оскільки різні теми вносять плутанину в ситуацію та негативно впливають на мовлення.

Важливим різновидом внутрішньої мотивації $\epsilon$ також інструментальна мотивація, тобто мотивація, яка випливає з позитивного ставлення студентів до певних видів роботи.

Відомо, що педагогічний ефект посилюється завдяки власній активності студентів, і його неможливо отримати у формі нейтральнопасивного сприйняття. Як наслідок такого підходу студенти матимуть методичний інструментарій для подальшого удосконалення навичок i вмінь з іноземної мови (Gardner \& Lambert, 1995).

Складність i багатоаспектність проблеми мотивації зумовлюють багатовимірність у розумінні іiі сутності, природи, структури, а також функцій окремих мотивів.

Різні дослідники використовують подібні, але не синонімічні, поняття для позначення цього феномену, а саме: навчальна мотивація, мотивація навчання, мотивація навчальної діяльності, мотиваційна сфера, мотиваційний синдром.

I. О. Зимня (2004) визначає навчальну мотивацію як окремий вид мотивації, що включено в діяльність навчання або навчальну діяльність. 


\section{Інноватика у вихованні. Випуск 13.Том 2. 2021.}

Як і для будь-якого іншого виду діяльності, навчальна мотивація визначається низкою специфічних для цієї діяльності чинників:

освітньою системою, закладом освіти, де відбувається навчальна діяльність;

особливостями організації освітнього процесу;

особливостями суб'єктів навчальної діяльності (вік, стать, інтелектуальний розвиток, здібності, рівень домагань, самооцінка, взаємодія із соціальним оточенням);

суб'єктними особливостями педагога i, передусім, системою його ставлень до учня /студента;

специфікою навчальної дисципліни.

Крім того, навчальна мотивація характеризується складною структурою, системністю, спрямованістю, динамічністю, стійкістю і пов'язана 3 рівнем інтелектуального розвитку і характером навчальної діяльності. А. К. Маркова підкреслювала ієрархічність її побудови: до їі складу входять потреби в навчанні, мета навчання, емоції, ставлення та інтерес (Маркова, 1983).

Іноді пригнічену мотивацію можна пояснити зниженою здатністю студента до концентрації та лінощами. Безперечно, неможливо силою зацікавити слухача, але існують шляхи формування мотивації студентів закладів вищої світи та підвищення їх навчальних досягнень:

щоденна увага до кожного студента, визнання його особистості;

своєчасна ліквідація прогалин у знаннях і організація оперативної допомоги кожному студентові, що відстає у навчанні;

формування мотивації учіння як необхідного стимулу бажання студента до навчання;

перехід до інноваційних методів навчання, що дають можливість розкрити потенційні можливості кожного студента, повірити у власні сили;

організація навчального процесу з визначенням трьох головних видів складності під час пояснення матеріалу, його закріплення і оцінювання;

поділ навчального матеріалу на кілька блоків у вивченні будь-якої теми;

навчання студентів аналізувати інформацію щодо можливості іiі застосування до пояснення нових явищ, встановлювати зв'язки з уже набутими раніше знаннями та досвідом, переносити знання і вміння 3 інформаційно-комунікаційних технологій i навчальних дисциплін на вирішення поставлених комунікативних завдань (Скакун та Матіюк, 2018).

Висновки i перспективи подальших розвідок. Звичайно, усі вищезазначені різновиди мотивації $є$ провідними аспектами у вивченні іноземної мови. Відомо, що висока мотивація $\epsilon$ ознакою ефективної діяльності особистості. Проте зазначаємо, у разі занадто високого рівня мотивації збільшуються рівні активності і напруги, внаслідок чого може знижуватися якість засвоєння навчального матеріалу. Таким чином, 


\section{Інноватика у вихованні. Випуск 13.Том 2. 2021.}

необхідність досягнути високого рівня мотивації викликає у студентів небажані емоційні реакції. Тому оптимальним рівнем мотивації навчання $\epsilon$ такий, при якому отримання позитивних емоцій від самого процесу навчання поєднується з високою ефективністю засвоєння знань.

Незважаючи на значну кількість публікацій і досліджень, проведених викладачами-практиками, та власних досліджень, проблема мотивації студентів закладів вищої освіти до вивчення іноземних мов у процесі їх професійної підготовки залишається й надалі надзвичайно актуальною. Розглянуті способи мотивації при вивченні іноземних мов сприятимуть підвищенню рівня знань 3 подальшим їх використанням у професійній діяльності.

\section{СПИСОК ВИКОРИСТАНИХ ДЖЕРЕЛ}

Бей, І. (2018). Формування позитивної мотивації студентів до використання проектних технологій у майбутній професійній діяльності вчителя іноземної мови : В: збірник наукових пращь Прикарпатського наи. ун-ту ім. В. Стефаника. Вип. 2. І.-Фр., СС. 17-25.

Зимняя, И. (2004). Педагогическая психология. И. А. Зимняя. М.: Логос, 384 с.

Знанецький, В. (2020). Щодо розвитку мотивації студентів до вивчення іноземної мови у процесі професійної підготовки. Стратегічні пріоритети в науизі :збірник наукових матеріалів XL Міжнар. наук.практ. конф., Вінниц. СС. 38-40.

Костенко, О. (2012) Мовою міжнародного спілкування в Україні має бути англійська. День. № 134.

Котлер, Ф. та Келлер, К. (2014). Маркетинг менеджмент. 14-е изд; пер. с англ. под. ред. В. Кузина. С.-Петерб. Питер, 800 с.

Латишев, Л. (2003). Теория, практика и методика преподавания. Москва: ИЦ «Академия». 192 с.

Маркова, А. (1983). Формирование мотивачии учения в школьном возрасте: пособие для учителя. М.: Просвещение. 96 с.

Рубан, Л. (2014). Мотивація студентів до вивчення іноземної мови на немовних факультетах. Вісник Харківського нац. ун-ту ім. В. Н. Каразіна. 78 (1103). Х. CC. 187-190.

Скакун, М. та Матіюк, Д. (2018). Підвищення мотивації студентів до вивчення німецької мови та формування готовності до неперервної освіти за допомогою сучасних інформаційно-комунікаційних технологій та мультимедійних засобів. Актуальні питання вивчення германських, романських $i$ слов'янських мов $і$ літератур та методики викладання іноземних мов : матеріали Всеукр. наук. конф., 18 трав. 2018 р. ДНУ ім. В. Стуса. Вінниця. СС.56-59.

Штохман, Л. (2017). Комунікативна складова у навчанні іноземної мови у ВНЗ. Молодий вчений. 3 (43). Київ. СС. 512-515.

Gardner, R., Lambert, W. (1995). Motivational variables in second language acquisition. Canadian Journal of Psychology. No 4. PP. 266-272. 


\section{REFERENCES}

Bei, I. (2018). Formuvannia pozytyvnoi motyvatsii studentiv do vykorystannia proektnykh tekhnolohii u maibutnii profesiinii diialnosti vchytelia inozemnoi movy [Formation of positive motivation in students in using project technologies in the future professional activity of a foreign language teacher]: V: zbirnyk naukovykh prats Prykarpatskoho nats. un-tu im. V. Stefanyka. Vyp. 2. I.-Fr. SS. 17-25. [in Ukrainian].

Zimnyaya, Y. (2004). Pedagogicheskaya psikhologiya [Pedagogical psychology]. Y. A. Zimnyaya. M.: Logos. 384 s. [in Russian].

Znanetskyi, V. (2020). Shchodo rozvytku motyvatsii studentiv do vyvchennia inozemnoi movy u protsesi profesiinoi pidhotovky. [Regarding to the development of students' motivation to learn a foreign language in the process of professional training]. Stratehichni priorytety $v$ nautsi :zbirnyk naukovykh materialiv XL Mizhnar. nauk.-prakt. konf., Vinnytsia. SS. 38-40. [in Ukrainian].

Kostenko, O. (2012). Movoiu mizhnarodnoho spilkuvannia v Ukraini maie buty anhliiska. [English should be the language of international communication in Ukraine]. Den. 2012. No 134. [in Ukrainian].

Kotler, F., Keller, K. (2014). Marketynh menedzhment [Marketing management]. F. Kotler, K.L. Keller; 14-e izd;. per. s anhl. pod. red. V. Kuzina. SPb.: Piter. 800 s. [in Russian].

Latyshev, L. (2003). Teoriya, praktika i metodika prepodavaniya [Theory, practice and teaching methods]. L.K.Latyshev. M.: ITs "Akademiya". 192 s. [in Russian].

Markova, A. (1983). Formyrovaniye motyvatsii ucheniya $v$ shkolnom vozraste [Formation of motivation for learning at school age]: posobiye dlya uchitelya / A. K. Markova. M.: Prosveshcheniye. 96 s. [in Russian].

Ruban, L. (2014). Motyvatsiia studentiv do vyvchennia inozemnoi movy na nemovnykh fakultetakh. [Motivation of students to study a foreign language at non-language faculties]. Visnyk Kharkivskoho nats. un-tu im. V. N. Karazina. 78 (1103). Kharkiv. SS. 187-190. [in Ukrainian].

Skakun, M., Matiiuk, D. (2018). Pidvyshchennia motyvatsii studentiv do vyvchennia nimetskoi movy ta formuvannia hotovnosti do neperervnoi osvity za dopomohoiu suchasnykh informatsiino-komunikatsiinykh tekhnolohii ta multymediinykh zasobiv [Increasing students' motivation to learn German and form readiness for further education by means of modern information and communication technologies and multimedia tools]. Aktualni pytannia vyvchennia hermanskykh, romanskykh $i$ slovianskykh mov i literatur ta metodyky vykladannia inozemnykh mov : materialy Vseukr. nauk. konf., 18 trav. $2018 r$. DNU im. V. Stusa. Vinnytsia. ss.56-59. [in Ukrainian].

Shtokhman, L. (2017). Komunikatyvna skladova u navchanni inozemnoi movy u VNZ. [Communicative component in teaching a foreign language in higher education]. Molodyi vchenyi. 3 (43). Kyiv. SS. 512-515. [in Ukrainian].

Gardner, R., Lambert, W. (1995). Motivational variables in second language acquisition. Canadian Journal of Psychology. No 4. PP. 266-272. 


\title{
MOTIVATION FOR STUDYING FOREIGN LANGUAGES AT HIGHER EDUCATIONAL INSTITUTIONS
}

Svitlana Denysova

teacher of foreign languages

Municipal Institution of Higher Education

"Lutsk Pedagogical College" of Volyn Regional Council,

ORCID: 0000-0001-9352-7036

e-mail: 1denusova.svitlana@gmail.com

Oksana Kuzmych

teacher of foreign languages

Municipal Institution of Higher Education

"Lutsk Pedagogical College" of Volyn Regional Council,

ORCID: 0000-0002-1335-3791

e-mail: kuzmych.o@ukr.net

Iryna Nikolaieva

teacher of foreign languages

Municipal Institution of Higher Education

"Lutsk Pedagogical College" of Volyn Regional Council,

ORCID: 0000-0002-2949-0002

e-mail:iri5272@ukr.net

\begin{abstract}
The article deals with the problem of motivation to learn foreign languages in higher education institutions. The description and generalization of the basic kinds of motivation, its structure and role at studying of a foreign language in high school has been carried out, the basic characteristics of motivation and their communication with process of training have been considered. Motivation is considered as a managerial activity in the process of foreign language training and as one of the main problems of its teaching methods. Foreign language as an academic discipline has many specific features, one of which is the mastery of a foreign language in the process of developing skills and abilities to communicate in a foreign language. Nowadays the relevance of learning a foreign language is beyond doubt, as the development of modern society, expanding international cooperation and international contacts, organizing conferences in higher education institutions with foreigners participations require a deeper knowledge of a foreign language by students

The problem of motivating students to study foreign languages while studying at a higher education institution were studied; the existing types of motivation were distinguished and its dominant role in the process of learning foreign languages by students was determined.. The role of the level of pedagogical skill of the teacher which contributes to the motivation of students to learn foreign languages was considered. The main types of internal motivation for the student in the context of learning a foreign language were outlined. The hierarchy and ways for forming students' learning motivation were indicated.It is noted that the optimal level of learning motivation is one in which obtaining positive emotions from the learning process itself is combined with high efficiency of knowledge acquisition.
\end{abstract}

Keywords: motivation, student, institution of higher education, foreign language learning, motivational factors, teacher's skill

Стаття надійшла до редакиії 22. 03. 2021 р. 